\title{
Olga Adamowska
}

Bydgoski Zespół Placówek Opiekuńczo Wychowawczych

\section{Małgorzata Henryka Kowalczyk}

Uniwersytet Mikołaja Kopernika w Toruniu

\section{Rola związków partnerskich w resocjalizacji i wykonywaniu kary wobec skazanych długoterminowych}

\section{The role of domestic partnerships during resocialization and the execution of the penalty towards long-term convicts}

Streszczenie. Długoterminowa kara pozbawienia wolności powoduje szereg dolegliwości psychicznych i społecznych. Odizolowanie od dotychczasowych warunków życia na wolności, od rodziny, przyjaciół zmienia zachowania osadzonych, którzy zaczynają coraz bardziej koncentrować się na aktualnej sytuacji. Prowadzi to do zerwania więzi z osobami bliskimi pozostającymi na wolności. Celem opracowania było zbadanie roli związków partnerskich zarówno w życiu skazanych, jak i w procesie resocjalizacji, a w szczególności ustalenie specyfiki tych związków, roli, jaką pełnią w życiu obojga partnerów, oraz ewentualnych zmian, jakie dzięki tym relacjom zaszły w zachowaniu badanych w trakcie pobytu w zakładzie karnym. Na podstawie badań przeprowadzonych w oparciu o strategię jakościową i przy wykorzystaniu metody wywiadu omówiono dwa typy związków. Na podstawie materiału badawczego wskazano na oczekiwania badanych par dotyczące związków, czynniki wzmacniające i osłabiające funkcjonowanie ich relacji oraz na prognozę penitencjarną.

Słowa kluczowe: kara pozbawienia wolności, kara długoterminowa, skutki izolacji, związki partnerskie, czynniki wzmacniające i osłabiające związki.

Summary. Long-term custodial sentence causes a number of psychological and social problems. Isolating from current living conditions, family, and friends changes the bahaviour of prisoners who begin to increasingly focus on their current situation. This influences bonds with close relatives who are at large. The aim of the article was to examine the role of domestic partnerships, not only in the life of the convicts, but also during the process of resocialization. Particularly, the main objective was to establish the specificity of these relationships, the role they perform in the life of both partners and possible changes resulting from the relationships which could be observed in the behaviour examined during the course of the stay in the penitentiary. With regard to the collected material, it was possible to present the 
respondents' expectations towards their relationships, strengthening and weakening factors influencing the functioning of relationships and the forecast of penitentiary.

Keywords: custodial sentence, long-term penalty, effects of the isolation, domestic partnerships, factors strengthening and weakening domestic partnerships.

\section{Wprowadzenie}

Kara pozbawienia wolności, w szczególności kara długoterminowa, jest karą związaną z największymi dolegliwościami - zarówno psychicznymi, jak i społecznymi. Tym samym generuje ona wiele sytuacji trudnych, będących obciążeniem nie tylko dla skazanych, ale także dla personelu więziennego oraz osób bliskich pozostających poza murami zakładu karnego. Długotrwałe odizolowanie od dotychczasowych warunków życia na wolności zmienia zachowania osadzonych, którzy zaczynają coraz bardziej koncentrować się na aktualnej sytuacji. Zwykle po etapie buntu następuje przystosowanie, które uświadamia osadzonemu, że oto najbliższe kilka, kilkanaście lat spędzi w zakładzie karnym. Głównym zadaniem absorbującym skazanych w tej fazie jest zorganizowanie sobie życia w nowych warunkach i ułożenie relacji ze współosadzonymi i personelem. Czy zatem pozostające poza murami więzienia partnerki życiowe mogą odegrać znaczącą rolę w życiu i wpłynąć na skuteczność oddziaływań penitencjarnych?

\section{Kara długoterminowa i jej reperkusje}

Długoterminowa kara pozbawienia wolności nie jest pojęciem prawnym, dlatego też jest różnie rozumiana. Zdaniem Józefa Wąsika jest to kara powyżej 3 lat pozbawienia wolności (Wąsik, 1981, s. 29). Henryk Machel natomiast przyjmuje za karę długoterminową, karę 25 lat pozbawienia wolności. Jego zdaniem kara dożywotniego pozbawienia wolności jest karą bezterminową, a nie długoterminową, gdyż nie można dokładnie określić czasu jej trwania (Machel, 2000, s. 193). Zróżnicowana interpretacja kary długoterminowej sugeruje niejednorodne warunki, jakie wiążą się z sytuacją skazanych. Inaczej w warunkach więziennych funkcjonuje skazany na karę powyżej 3 lub 5 lat niż skazany, który w zakładzie karnym musi spędzić 25 lat. Biorąc pod uwage przewidziane przez ustawodawcę dobrodziejstwa łagodzące wymiar kary w postaci warunkowego przedterminowego zwolnienia, 
skazani na 25 lat spędzą w więzieniu minimum 15 lat, dlatego tak ważne jest, by nie zatracili oni kontaktu z wolnością i umieli z tej wolności, po latach bezwzględnej izolacji, korzystać. Wieloletni pobyt w odosobnieniu wywołuje traumatyczne doświadczenia nie tylko u samych osadzonych, ale także członków ich rodzin, niejednokrotnie w sposób nieodwracalny zmieniając ich sytuację życiową. Nie można jednak zapomnieć, że dla niektórych rodzin pobyt jej bliskiego w izolacji otwiera możliwości uporządkowania sytuacji rodzinnej i rozpoczęcia nowego, spokojnego życia bez przemocy, awantur czy alkoholu.

Istotnym następstwem pobytu członka rodziny w zakładzie karnym jest zwykle stygmatyzacja i marginalizacja, którą odczuwają partnerki i dzieci oraz inni krewni skazanych. Negatywne reakcje często prowadzą do ograniczenia kontaktów z uwięzionym, ukrywania faktu pobytu w więzieniu lub nawet zmiany miejsca zamieszkania (Marchel-Kosiorek, 2010, s. 161; Kasprowicz, Giermacka, 2010, s. 209-210). W przypadku skazanych długoterminowych zmienia się diametralnie nie tylko sytuacja społeczna i ekonomiczna rodziny. U dzieci pozbawienie pełnej opieki rodzicielskiej powoduje zaburzenia w zachowaniu, skłonność do ujawniania zachowań ryzykownych i zwiększa prawdopodobieństwo powielania przestępczych wzorców rodzicielskich (Marczak, 2012, s. 243; Hołyst, 2011, s. 161).

\section{Kontakty z rodziną a resocjalizacja a funkcjonowanie skaza- nego w warunkach izolacji więziennej}

Rodzina jest niezwykle ważnym sojusznikiem pracowników zakładu karnego w realizowaniu oddziaływań resocjalizujących. To właśnie osoby z najbliższego środowiska osadzonego mają największy wpływ na podejmowane przez niego role społeczne, przyjmowane wartości, wzory i normy zachowań. Dzięki podtrzymywaniu więzi rodzinnych skazani mogą utrzymywać równowagę psychiczną. Kontakt z najbliższymi osobami wpływa na utrzymanie odpowiedniej samooceny i odczuwanie satysfakcji emocjonalnej. Skazani, identyfikując się z rodziną, mają przeświadczenie, że nadal są jej członkami i są ważni w życiu bliskich osób (Rzepliński, 1981, s. 13-16). Takie relacje stanowią przeciwwagę dla ograniczeń płynących z izolacji więziennej, a także dla antagonizmów występujących w relacjach personelu ze społecznością skazanych. Dzięki temu zmniejsza się dystans społeczny w społeczności zakładu karnego, a tym samym zwiększa się skuteczność oddziaływań resocjalizacyjnych (Kuć, 2009, s. 119). Szczególną rolę odgrywać może 
wsparcie ze strony osób najbliższych, poczucie istnienia więzi emocjonalnej łączącej z partnerem życiowym. Według Tadeusza Sakowicza to właśnie rodzina prokreacyjna, a nie generacyjna, ma większy wpływ na osadzonego, ze względu na silniejsze więzi uczuciowe. Częste kontakty z nią redukują niektóre negatywne skutki izolacji więziennej, a także mają wartość terapeutyczną w eliminowaniu różnych form napięcia nerwowego (Sakowicz, 2009, s. 83).

Posiadanie osób bliskich, na których pomoc, wsparcie zarówno podczas pobytu w izolacji, jak i po wyjściu z zakładu karnego można liczyć, należy uznać za znaczący czynnik nie tylko obniżający poczucie deprywacji, ale także ułatwiający readaptację społeczną skazanych. Z drugiej jednak strony nie można wykluczyć sytuacji, w której tworzenie lub utrzymywanie związków przez osadzonych nie zmienia ich zachowań wobec kobiet, które pozostaje instrumentalne lub w innym względzie niewłaściwe, co wyklucza możliwość utworzenia wartościowej i trwałej relacji.

\section{Cel i metoda}

Głównym celem podjętych badań było zbadanie znaczenia związków partnerskich zarówno w życiu skazanych, jak i w procesie resocjalizacji, a w szczególności ustalenie roli, jaką pełnią w życiu obojga partnerów, oraz ewentualnych zmian, jakie dzięki tym relacjom zaszły w zachowaniu skazanych w trakcie pobytu w zakładzie karnym. Dla uzyskania danych analizie poddano wybrane elementy sytuacji życiowej badanych. Na potrzeby badań został sformułowany następujący problem badawczy: Jakie znaczenie dla skazanych odbywających kary długoterminowe mają zawarte przez nich w warunkach izolacji związki?

Ponadto zdefiniowano następujące problemy szczegółowe:

1. Jakie są oczekiwania badanych związane z powstałym związkiem?

2. Jakiego rodzaju potrzeby mogą być zaspokajane w relacjach z partnerkami?

3. Czy badana relacja oddziałuje na zachowanie osadzonego w zakładzie karnym i udział w procesie resocjalizacji? A jeśli tak, to w jaki sposób?

W badaniach użyto strategię jakościową, w ramach której zastosowano badania diagnostyczne. W celu zebrania materiału badawczego posłużono się metodą wywiadu, jako technikę badań wykorzystano wywiad indywidualny, częściowo przygotowany przez autorki badań. Materiał badawczy uzy- 
skany w trakcie przeprowadzonych wywiadów został opracowany zgodnie ze schematem analizy danych jakościowych (Corbin, 2005).

\section{Rola związków partnerskich w resocjalizacji skazanych długo- terminowych w świetle badań}

\section{Związek wyidealizowany - obraz życzeniowy}

Zwiqzek Adama i Danuty. Adam (urodzony w 1982 roku) odbywa aktualnie karę 25 lat pobawienia wolności za zabójstwo. Koniec kary nastąpi w 2026 roku. Mężczyzna przebywa w zakładzie typu zamkniętego, co uniemożliwia mu korzystanie z przepustek systemowych. Danuta (urodzona w 1981 roku) poznała męża już w trakcie odbywania przez niego kary. Związek Adama i Danuty trwa od czterech lat, od trzech są małżeństwem. Ich relacja stanowi przykład związku, w którym silnie pragnienie „bycia z kimś”, posiadania żony/męża zaważyło na decyzji obojga. Choć partnerzy deklarują silną więź, ich związek opiera się raczej na wyobrażeniu miłości niż na rzeczywistym doświadczaniu tego uczucia. Badanych łączą podobne doświadczenia rodzinne charakteryzujące się deficytem uczuć. Niedostatek zainteresowania ze strony rodziców spowodował u obojga niezaspokojone potrzeby uznania, bezpieczeństwa, miłości, a to w konsekwencji wpłynęło na dużą nieufność i podejrzliwość wobec partnerów w dotychczasowych związkach.

Tak, miałem narzeczona, ale zdradziła mnie. [...] Zawsze najważniejsza była dla mnie lojalność i szacunek, a ona mnie zdradziła. Później się tłumaczyła, że nie chciała. [Adam]

...trwały krótko i chociaż dla mnie były ważne, dla tych osób nie za bardzo, zależało im po prostu tylko na jednym [...] czuje się zraniona i nie było sensu dalej tego ciągnać [...] po tych znajomościach z moimi byłymi nie miałam za bardzo ochoty zapoznawać kogokolwiek. [Danuta]

\section{(KODTEO 1 Dotychczasowe relacje partnerskie charakteryzowały} się podejrzliwością i nieufnością wobec partnerów przy jednoczesnym nieprzemyślanym wyborze partnerów)

Badani, decydując się na stworzenie związku, kierowali się przede wszystkim silną potrzebą posiadania drugiej osoby, która dawałaby poczucie przynależności i zmieniała dotychczasowy status. Wypowiedzi obojga 
wskazują, że związek ten ma dla nich wyjątkową wartość. Deklarują wzajemną miłość, planują wspólną przyszłość, bagatelizując realia.

Na pewno chcemy mieć dzieci, ja już i tak będę miał bardzo odpowiedni wiek. [...] Moim zdaniem właśnie tak powinno być, to mężczyzna powinien zadbać, żeby kobiecie nic nie brakowało, kobieta powinna być $w$ domu, dbać o dzieci i męża, no i o dom. [Adam]

[...] chciałabym mieć dzieci prawdziwy dom rodzinny, bo tego mi brakuje, po prostu normalnie i spokojnie żyć. [...] stałam się szczęśliwsza, że znalazłam osobę, z która dzielę swoje radości i smutki, że mam nie tylko kochanka, ale i przyjaciela, na którego mogę liczyć, chociaż jest daleko. [Danuta]

\section{(KODTEO 2 Stworzenie związku partnerskiego daje możliwość za- spokojenia ważnych potrzeb emocjonalnych i wpływa na pozytyw- ną ocenę związku)}

Pozornie, z wypowiedzi obojga można wysnuć wniosek, że tworzą związek doskonały, oboje są bardzo zaangażowani. Należy jednak pamiętać, że para ta nigdy nie miała możliwości zweryfikowania swoich uczuć, wzajemnych oczekiwań i zachowań w warunkach pozawięziennych. Ich kontakt opiera się przede wszystkim na rozmowach telefonicznych, listach i sporadycznych (raz na kilka miesięcy) widzeniach. Adam, mimo wcześniejszych deklaracji i głębokiej miłości do żony, sugeruje jednak, że nie ufa jej bezgranicznie. Oboje pragną mieć dzieci, dom, jednak można mieć wątpliwości, czy oboje mają taką samą wizję przyszłości. Nie biorą pod uwagę między innymi wieku, w jakim będą, gdy zakończy się kara Adama. Osadzony jest pewny, że gdy opuści zakład karny, żona porzuci pracę zawodową na rzecz opieki nad dziećmi i zajmowania się domem, ma zdecydowanie ugruntowane przekonania dotyczące podziału ról w rodzinie. Danuta usilnie dąży do poczucia bezpieczeństwa, co w jej mniemaniu zapewnić ma posiadanie męża i dzieci. W związku to Adam jest osobą dominującą. Badany stwierdza, że zna żonę lepiej niż ona sama. Kobieta przypisuje mu wiele zasług, w szczególności swoje poczucie własnej wartości opiera na opiniach męża. Wyidealizowana wizja związku aktualnie stanowi dla nich silny mechanizm napędowy pozwalający na zaspokojenie ważnych potrzeb psychicznych, a w przypadku Adama wpływa dodatkowo na zmianę jego zachowania.

Dzięki niej jestem grzeczniejszy, choć czasem mam ochotę być ten zły, to dzięki niej się hamuję. [...] Nie zamierzam w żadnym wypadku tutaj wrócić, chcę mieć własnq 
firmę, zarabiać na rodzinę. [...] Pewnie, jest ktoś, kto na mnie czeka [łatwiej odbywać karę pozbawienia wolności]. Tak, uczę się, pracuję, robię co się da. [Adam]

Mam nadzieję, że dzięki mojej osobie stał się lepszym człowiekiem. [Danuta]

\section{(KODTEO 3 Stworzenie związku partnerskiego pozytywnie wpływa na zachowanie skazanego oraz udział $w$ oddziaływaniach peniten- cjarnych)}

W funkcjonowaniu Adama nastąpiła wyraźna poprawa. Unika zachowań ryzykownych, konfliktów ze współosadzonymi i personelem więziennym, aktywnie uczestniczy w różnych formach oddziaływań penitencjarnych. Deklaruje odpowiedzialność za przyszłą rodzinę. Należy jednak sądzić, że po 25 latach spędzonych w warunkach izolacji readaptacja społeczna będzie niezwykle trudna. Rozpoczęcie wówczas wspólnego życia, próby podjęcia realizacji planów oraz konieczność zmierzenia się z trudnościami codziennego wspólnego życia zweryfikują siłę więzi między nimi.

\section{Znaczenie związku w prognozie resocjalizacyjnej}

$$
\begin{aligned}
& \text { czynniki } \\
& \text { wzmacniajace }
\end{aligned}
$$

\section{czynniki \\ osłabiajace}

Adam i Danuta

- zawarcie związku małżeńskiego

- wspólne plany na przyszłość

- podobne doświadczenia życiowe

- systematyczny kontakt telefo-

niczny i listowny

- udział osadzonego w oddziały-

waniach resocjalizacyjnych
- bardzo rzadkie kontakty osobiste tylko w trakcie widzeń w zk - odległy koniec kary

- brak wsparcia ze strony rodzin

- brak możliwości korzystania

z przepustek systemowych

\section{Nota teoretyczna}

Związek Adama i Danuty na obecnym etapie jest związkiem pozytywnie rokującym z perspektywy efektów resocjalizacji. Stanowi istotne wzmocnienie motywacji badanego, wpływa korzystnie na jego zachowanie i aktywne uczestnictwo w oddziaływaniach penitencjarnych. Pozytywny wymiar związku wynika przede wszystkim z możliwości zaspokojenia ważnych po- 
trzeb emocjonalnych, które uległy deprywacji w dotychczasowych relacjach, także w relacjach rodzinnych. W przypadku Adama dodatkowym czynnikiem jest potrzeba posesywnego traktowania partnerki, które kobieta akceptuje, ponieważ na obecnym etapie stanowi to także zaspokojenie potrzeby przynależności.

\section{Związek z szansą na przetrwanie - obraz urealniony}

Zwiq̨zek Sławomira i Anny. Sławomir (urodzony w 1976 roku) aktualnie odbywa karę 25 lat pozbawienia wolności za zabójstwo ze szczególnym okrucieństwem. Koniec kary nastąpi w 2025 roku. Przebywa w zakładzie typu półotwartego, co umożliwia mu korzystanie z przepustek systemowych. Anna - rówieśnica Sławomira - poznała partnera w trakcie jego pobytu w zakładzie karnym. Para jest razem od 5 lat, w najbliższym czasie planują ślub. Ich związek umacnia przeciwieństwo cech, a w przypadku Sławomira także potrzeba otaczania opieką przyszłej żony, która jest osobą nieśmiałą i mało zaradną życiowo. Dla badanego pokładana w nim ufność i podporządkowanie są źródłem satysfakcji i poczucia dumy. Oboje wywodzą się z rodzin funkcjonalnych, pełnych, bez cech patologicznych. Lepszy klimat emocjonalny i atmosferę wychowawczą stworzyli rodzice Sławomira. Pewne symptomy wskazujące na problemy rodzinne pojawiły się w rodzinie Anny, dotyczyły one jednak bardziej relacji rodzicielskich niż wzajemnych więzi rodzice-dzieci. Badana czuła się kochana i akceptowana. Osłabienie kontaktów z ojcem nastąpiło dopiero w trakcie związku ze Sławomirem, którego przeszłości kryminalnej ojciec nie akceptuje. Oboje badani stworzyli już wcześniej związki, które z różnych względów nie przetrwały próby czasu. Sławomir wątpił, czy pierwsza żona będzie chciała czekać na niego 25 lat, zatem wniósł sprawę o rozwód. Anna stworzyła nieudane związki, które stały się źródłem jej cierpienia.

Tak, byłem żonaty. W momencie, kiedy trafiłem do więzienia, rozwiodłem się. To była moja decyzja, nie chciałem, żeby się tak dla mnie poświęcała, tak długo czekała. Od razu złożyłem papiery rozwodowe. [Sławomir]

Byłam $w$ kilku zwiqzkach, w jednym dłuższym. Zawsze $w$ końcu się kończyło, zawsze cierpiałam. Nie wiem czym się kierowałam, chyba po prostu szukałam bliskości, chciałam być kochana, czuć, że komuś na mnie zależy [...] byłam okłamywana, zdradzana. Chyba zbyt łatwo przebaczałam. [Anna] 


\section{(KODTEO 1 Dotychczasowe relacje partnerskie charakteryzował brakiem zaufania wobec partnerów przy jednoczesnym nieprzemy- ślanym wyborze partnerów)}

Badany jest osobą, która świetnie potrafi manipulować i kierować ludźmi. Jest świadomy swojego wpływu na innych i chętnie to wykorzystuje. Anna w opinii partnera jest osobą naiwną i łatwowierną, co sama przyznaje. Cechy te sprawiają, że łatwo ją wykorzystać, na co wskazują doświadczenia z wcześniejszych związków. Kobieta jest zdolna do wielu poświęceń dla partnera, by tylko otrzymać choć trochę zainteresowania i czuć się kochaną.

Jest to bardzo czuła osoba, wyrozumiała, ale też bardzo infantylna i naiwna. Lubię to $w$ niej, ale przez to też muszę bardziej nad nia czuwać. Bardzo łatwo ja zranić. [...] Ona nie ma złych cech. Rozmawiamy o rodzinie, chcemy w przyszłym roku wziąć ślub. [Sławomir]

Jestem szczęśliwa, choć nie jest to łatwe. Wiem, że wszystko będzie dobrze. Dzięki Sławkowi $w$ to wierzę, ale czasami jest mi ciężko. [...] w końcu będziemy małżeństwem, nie wyobrażam sobie zrobić coś bez wiedzy Sławka. [Anna]

\section{(KODTEO 2 Stworzenie związku partnerskiego daje możliwość za- spokojenia ważnych potrzeb emocjonalnych i wpływa na pozytyw- ną ocenę związku)}

Ze słów badanych wynika, że stworzony związek ma bardzo duże znaczenie, choć każde z nich inaczej to postrzega. Sławomir po kilku latach spędzonych w izolacji uznał, że brak partnerki mocno mu doskwiera, zatem zdecydował się na stworzenie nowej relacji, w której jest osobą dominującą, wspierającą partnerkę. Dla Anny związek ze Sławomirem stanowi spełnienie jej marzeń o idealnym partnerze, który jest opiekuńczy, czuły, troszczy się o nią, a przynajmniej taką troskę deklaruje. Fakt popełnienia zbrodni nie jest dla niej istotny. Obydwoje twierdzą, że chwile spędzone razem są dla nich najważniejsze, jednak nie korzystają z widzeń. Kontakt utrzymują dzięki przepustkom oraz codziennym rozmowom telefonicznym. Pobyt w zakładzie karnym bardzo zmienił Sławomira. Uczestniczy aktywnie w programach resocjalizacyjnych, podejmuje nieodpłatne prace na rzecz zakładu karnego.

[Przestępstwo] To już w ogóle nie wchodzi w grę. Jak już mówiłem - to był nieprzemyślany i głupi czyn. Teraz mam zupełnie inny obraz siebie. Nie mogę sobie pozwolić na kolejna karę. Łatwiej mi tu być, przystosować się, ale to przyszło samo, nie dzięki związkowi. [Sławomir]

Mam nadzieję, że dzięki mnie jest łatwiej [odbywać karę]. [Anna] 


\section{(KODTEO 3 Stworzenie związku partnerskiego pozytywnie wpływa na zachowanie skazanego oraz udział $w$ oddziaływaniach peniten- cjarnych)}

W przypadku Sławomira chęć szybszego opuszczenia zakładu karnego (warunkowe przedterminowe zwolnienie) stanowiła pierwotny motyw jego postępów w resocjalizacji i zmiany zachowania. Związek z Anną wzmacnia jego motywację, ale nie determinuje bezpośrednio jego zachowań. Mężczyzna znaczenie związku postrzega raczej z perspektywy potwierdzenia swojej samooceny i świadomości, że jest potrzebny partnerce.

\section{Znaczenie związku w prognozie resocjalizacyjnej}

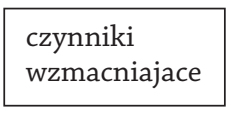

czynniki

osłabiajace

Sławomir i Anna

- planowanie zawarcia związku małżeńskiego

- regularne spotkania $\mathrm{w}$ trakcie przepustek

- codzienny kontakt telefoniczny

- udział badanego w oddziaływa-

niach resocjalizacyjnych
- odległy koniec kary

- brak akceptacji związku przez

ojca badanej

- różnice w poglądach religijnych

\section{Nota teoretyczna}

Związek Sławomira i Anny jest związkiem pozytywnie rokującym zarówno z perspektywy resocjalizacyjnej, jak i możliwości readaptacyjnych. Jest to związek dwojga osób o odmiennych typach osobowości, ale spełniający ich aktualne oczekiwania. Dla mężczyzny stanowi realizację potrzeby posiadania partnerki, która jest całkowicie uległa i którą może kontrolować. Dla kobiety związek jest spełnieniem oczekiwań związanych z potrzebą przynależności i bycia kochaną. W przypadku badanego stworzony związek podtrzymuje silną motywację do zmiany zachowania i przedterminowego opuszczenia zakładu karnego, co pozytywnie może rokować także w procesie readaptacji. 


\section{Podsumowanie}

Przedstawiony w niniejszym opracowaniu wycinek obszernych badań związanych z rolą związków w procesie resocjalizacji i odbywaniu kary wskazuje na pozytywny ich wpływ z perspektywy prognozy penitencjarnej. Trudno natomiast wnioskować o trwałości tych relacji. W przypadku skazanych stanowią one antidotum na nudę więzienną, realizację niezaspokojonych potrzeb emocjonalnych, a niekiedy także potrzebę posesywnego traktowania drugiej osoby. Związki te mimo różnego stażu i statusu zatrzymały się w fazie „miodowego miesiąca”, nie zakłócają ich funkcjonowania codzienne problemy, powierzchowna jedynie wzajemna znajomość czy konieczność kompromisów. Badane kobiety tworzą wyidealizowane wizje związków, bo spełniają one podstawowe oczekiwania, czyli posiadanie kogoś bliskiego, kogoś, o kim można mówić „mąż” lub „narzeczony”, a którego nieobecność jest akceptowana, gdyż codzienność nie weryfikuje póki co idealnej wizji związku.

\section{Bibliografia}

Corbin J., Holt N. L. (2005), Grounded theory, [w:] B. Somekh, B. Levin (red.), Research Methods in The Social Science, SAGE Publications, London.

Hołyst B. (2011), Wiktymologia, Wydawnictwo Lexis Nexis, Warszawa.

Kasprowicz A., Giernacka K. (2010), Sytuacja rodzin osób pozbawionych wolności, [w:] L. Pytka, B. Nowak (red.), Problemy wspótczesnej resocjalizacji, Wydawnictwo Pedagogium, Warszawa, s. 202-210.

Kuć M. (2009), Rola społeczeństwa w resocjalizacji skazanych odbywajacych karę pozbawienia wolności, [w:] A. Jaworska (red.), Resocjalizacja, Wydawnictwo Impuls, Kraków.

Machel H. (2000), Więzienie jako instytucja karna i resocjalizacyjna, Wydawnictwo Arche, Gdańsk.

Marchel-Kosiorek E. (2010), Kara - jej skutki i korelaty psychospołeczne, [w:] L. Pytka, B. Nowak (red.), Problemy wspótczesnej resocjalizacji, Wydawnictwo Pedagogium, Warszawa, s. 156-169.

Marczak M. (2012), Uwięziona jednostka czy uwięziona rodzina? O funkcjonowaniu rodzin osób przebywających w warunkach izolacji więziennej, [w:] W. Ambrozik, A. Kieszkowska (red.), Tożsamość grupowa dewiantów a ich reintegracja społeczna, Wydawnictwo Impuls, Kraków, s. 233-244. 


\section{8 | Olga Adamowska, Małgorzata Henryka Kowalczyk}

Rzepliński A. (1981), Rodziny więźniów długoterminowych, Wydawnictwo Ossolineum, Wrocław.

Sakowicz T. (2009), Wybrane aspekty środowiska rodzinnego w percepcji i ocenie osób osadzonych w polskich zakładach karnych, Wydawnictwo Impuls, Kraków.

Wąsik J. (1981), Kara krótkoterminowego pozbawienia wolności w Polsce, Wydawnictwo Ossolineum, Warszawa. 